\title{
Taxonomy of voles of the subgenus Sumeriomys Argyropulo, 1933 (Rodentia, Arvicolinae, Microtus)
}

\author{
Fedor N. Golenishchev, Olga V. Sablina, Pavel M. Borodin \& \\ Svyatoslav Gerasimov
}

\begin{abstract}
Dentition and baculum morphology in social voles of the subgenus Sumeriomys from the Southern Europe, Caucasus and Central Asia were examined. The specimens investigated come from 20 different sites, majority of which are the type localities for the nominal species-level taxa. Also results of the study of the karyotype, including differentially stained chromosomes for social voles from different parts of their geographic range and their hybrids are discussed. The synaptoneme complexes (SCs) for study of the chromosome pairing in different forms of voles was investigated. ForMicrotus $($ S.) schidlovskii Argyropulo, 1933 and M. (S.) paradoxus Ognev et Heptner, 1928 a species status is confirmed by our research. Two new subspecies of $M(S)$. socialis Pallas, 1773 are described: $M$. s. aristovi Golenishchev ssp. nov. and $M$. s. zaitsevi Golenishchev ssp. nov. The identification keys based on the baculum structure for the subgenus Sumeriomys are presented.
\end{abstract}

KEY WORDS: Microtus, Sumeriomys, taxonomy, distribution, morphology.

Fedor N. Golenishchev [microtus@zin.ru], Zoological Institute, Russian Academy of Sciences, Universitetskaya nab. 1., St. Petersburg 199034 Russia; Olga V. Sablina [sablina@bionet.nsc.ru], Institute of Cytology and Genetics, Siberian Branch of the Russian Academy of Sciences, pr. Lavrent'eva 10, Novosibirsk 630090 Russia; Pavel M. Borodin [borodin@bionet.nsc.ru], Institute of Cytology and Genetics, Siberian Branch of the Russian Academy of Sciences, pr. Lavrent'eva 10, Novosibirsk 630090 Russia; Svyatoslav Gerasimov, Institute of Zoology, Bulgarian Academy of Sciences, Tsar Osvoboditel 1, Sofia 100, Sofia Bulgaria.

\section{Таксономия полевок подрода Sumeriomys Argyropulo, 1933 (Rodentia, Arvicolinae, Microtus)}

\author{
Ф.Н. Голенищев, О.В. Саблина, П.М. Бородин, С.Герасимов
}

РЕЗЮМЕ. Исследовалось строение зубной системы и бакулюма у общественных полевок подрода Sumeriomys из южной Европы, Кавказа и Средней Азии. Изученный материал происходит из 20 различных точек, большинство из которых являются типовыми местонахождениями для номинальных таксонов видового уровня. Обсуждаются также результаты изучения кариотипов, в том числе дифференциально окрашенных хромосом общественных полевок из разных точек ареала, а также их гибридов. Исследовался синаптонемный комплекс (СК) для изучения спаривания хромосом у разных форм полевок. Подтвержден видовой статус Microtus (S.) schidlovskii Argyropulo, 1933 и $M$. (S.) paradoxus Ognev et Heptner, 1928. Выделено два новых подвида в пределах M. socialis Pallas, 1773: M. s. aristovi Golenishchev ssp. nov. и M. s. zaitsevi Golenishchev ssp. nov. Составлена определительная таблица для подрода Sumeriomys по строению бакулюма.

КЛЮЧЕВЫЕ СЛОВА: Microtus, Sumeriomys, таксономия, распределение, морфология.

\section{Introduction}

The subgenus of social voles (Sumeriomys Argyropulo, 1933) units some species and forms of unclear taxonomic status. There are several opinions on the taxonomic composition of this subgenus. According to Argyropulo (1933), the subgenus includes the social vole, M. socialis Pallas, 1773 (with the subspecies M. s. socialis, M. s. paradoxus Ognev et Heptner, 1928, and M. s. irani Thomas, 1921), the Guenther' vole, $M$. guentheri Danford et Alston, 1880, and the Schidlovski' vole, M. schidlovskii Argyropulo, 1933, as well as some forms of unclear taxonomic status from the Middle East. Ellerman (1941) considered within the M. socialis three subspecies: M. s. irani, M. s. paradoxus and M. s. schidlovskii. However, later he considered M. iranias an independent species (Ellerman \& Morrison-Scott, 1951). Corbet \& Hill (1980) and Harrison \& Bates (1991) attributed all the nominal forms of Sumeriomys to the single speciesM. socialis. Zykov \& Zagorodnyuk (1988) reestablished the taxonomic status of the $M$. paradoxus as an independent species, based on some morphological differences between the latter form and M. socialis and a lack of hybrids between $M$. paradoxus and $M . s$. 
Table 1. Materials investigated on the social voles (subgenus Sumeriomys) Collected in the field.

\begin{tabular}{|c|c|c|}
\hline Taxon and locality & $\begin{array}{l}\text { Number of alive } \\
\text { individuals collected }\end{array}$ & $\begin{array}{l}\text { Number of museum specimens } \\
\text { collected, either dry or fixed in alcohol }\end{array}$ \\
\hline $\begin{array}{l}\text { M. socialis nikolajevi } \\
\text { Ukraine, Kherson Prov., Kuyuk-Tuk* } \\
\text { Ukraine, Kherson Prov., Askania Nova Resenve } \\
\text { Ukraine, Crimea: } \\
\text { vicinity of Dzhankoy, } \\
\text { Sovetskii settlement } \\
\text { Peschanoye village } \\
\text { Vicinity of Kerch }\end{array}$ & 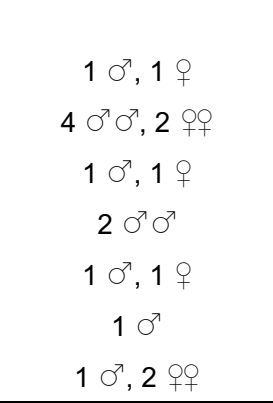 & $1 \sigma^{7}, 2$ 우 \\
\hline $\begin{array}{l}\text { M. s. binominatus } \\
\text { Georgia, vicinity of Tbilisi* }\end{array}$ & $6 \bigcirc^{7} \odot^{7}, 8$ 우 & $5 \odot^{7} \sigma^{7}, 6$ 우 \\
\hline $\begin{array}{l}\text { M. s. goriensis } \\
\text { Georgia, Tamarasheni settlement* }\end{array}$ & $10 O^{\top} O^{x}, 4$ 우 & \\
\hline $\begin{array}{l}\text { M. s. parvus } \\
\text { Russia, Stavropol Prov., Divnoye settlement* } \\
\text { Russia, Daghestan, Kaspiisk settlement }\end{array}$ & 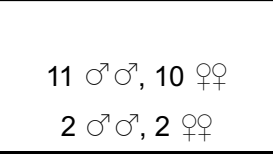 & \\
\hline $\begin{array}{l}\text { M. schidlovskii } \\
\text { Armenia, Talin District, Maralik settlement, } 40 \mathrm{~km} \mathrm{SW} \\
\text { from the type locality } \\
\text { Armenia, Vedin District, Khosrov Reserve }\end{array}$ & 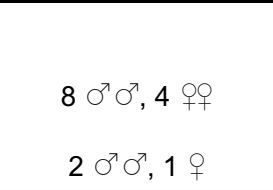 & \\
\hline $\begin{array}{l}\text { M. paradoxus } \\
\text { Turkmenistan, Kopetdagh Mountains, Dushak Mountain* }\end{array}$ & $4 \bigcirc^{7} O^{7}, 4$ 우 & \\
\hline $\begin{array}{l}\text { M. guentheri strandjensis } \\
\text { Bulgaria, Burgas Prov., vicinity of Sozopol, } 25 \mathrm{~km} \mathrm{~N} \text { from } \\
\text { the type locality }\end{array}$ & $6 \bigcirc^{7} O^{7}, 7$ 우 & \\
\hline
\end{tabular}

* terra typica.

** the material was present by A.E. Zykov.

nikolajevi Ognev, 1950 in the laboratory interbreeding. However, these authors lack comparative materials from other subspecies, taken from the type localities, and a number of hybridization experiments (six) was not sufficient enough, which was appreciated by the authors themselves. Some authors (Akhverdyan, 1989; Akhverdyan et al., 1991a, b) tried to demonstrate a species status for the M. schidlovskii. But, unfortunately, the voles collected by them for karyologic analysis and hybridization experiments were derived not from the type localities of the nominal forms. More recently, Musser \& Carleton (1993) listed three species for the subgenus - M. guentheri, M. socialis, and M. irani. According to Gromov (Gromov \& Erbaeva, 1995), in addition to $M$. socialis, also $M$. schidlovskii and $M$. paradoxus should be treated as distinct species. Pavlinov et al. (1995) considered the $M$. schidlovskii and $M$. paradoxus as junior subjective synonymous for the $M$. socialis and M. irani respectively.

Although the diploid chromosome count for $M$. socialis has long been known (Matthey, 1953), the karyotype of populations from different parts of the geographic range of the subgenus has been investigated quite superficially. This does not provide data enough for the assessment of the taxonomic status for some poorly known geographic races and elaborating of the taxonomic structure for the whole subgenus. Our work is devoted to the partial filling of this gap and presents the results of our taxonomic revision of the subgenus Sumeriomys from the territory of the former USSR.

\section{Materials and methods}

The materials investigated in this paper were collected during the field expeditions in the years 1985, 1987, 1990, 1991 (Tab. 1). The specimens were collected predominantly from the type localities (terra typica) of the nominal species level taxa within the subgenus Sumeriomys, or from the regions approximating the type localities (Fig. 1). Alive animals collected were kept in the vivarium of the Zoological Institute in Saint Petersburg under the standard laboratory conditions, satisfying the requirements of the instruction 12000-496, approved by the Presidium of the Academy of Sciences of the USSR on April 2, 


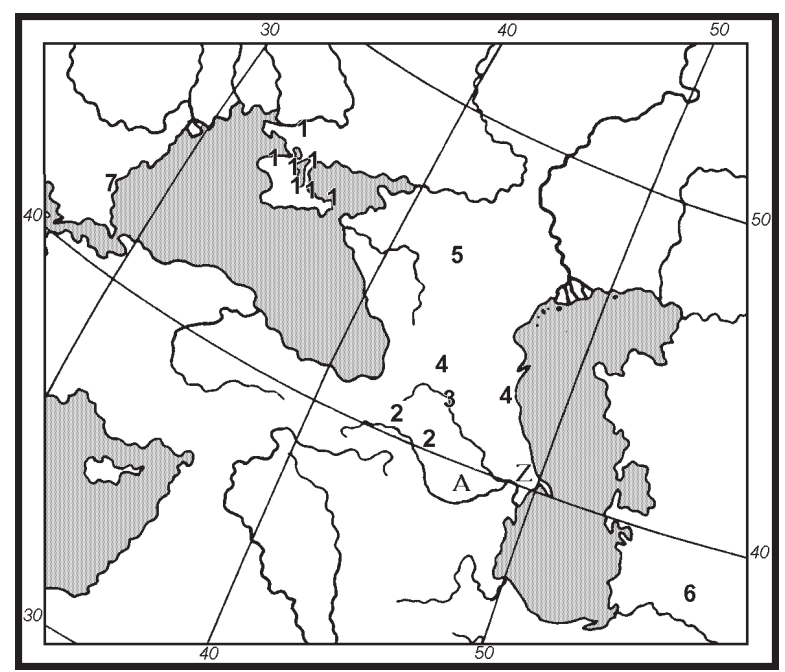

Figure 1. THE LOCALITIES OF THE SUMERIOMYS SPECIMENS EXAMINED: $1-M$. s. nikolajevi, $2-M$. schidlovskii, $3-$ M. s. binominatus, $4-$ M. s. goriensis, $5-$ M. s. parvus, $6-$ M. paradoxus, $7-M$. guentheri strandjensis, A - M. socialis aristovi $\mathbf{s s p}$. nov., Z - M. socialis zaitsevi ssp. nov.

1980, and of the order 22 issued by the Ministry of Higher Education on September 13, 1984.

The molars and skull structure and pelage coloration were investigated in 120 museum specimens, collected in the field, and in 152 specimens which were born in the laboratory. All materials examined are housed in the Zoological Institute, Russian Academy of Sciences, St. Petersburg collection (abbreviated ZIN). The baculum structure was investigated in all nominal forms mentioned in Tab. 1, as well as in specimens of M. s. socialis from the right bank of the Emba River, Gur'ev Province of Kazakhstan, of M. s. gravesi Goodwin 1934 from

Table 2. Baculum measurements IN SUMERIOMYS SPECIES (IN mm). AVERAGE (FIRST LINE) AND LIMITS OF VARIATION (SECOND LINE).

\begin{tabular}{|c|c|c|c|c|c|c|}
\hline Taxon and locality & $\mathrm{n}$ & $\begin{array}{l}\text { Total } \\
\text { length }\end{array}$ & $\begin{array}{l}\text { Shaft's } \\
\text { length }\end{array}$ & $\begin{array}{l}\text { Width of the } \\
\text { shaft's base }\end{array}$ & $\begin{array}{l}\text { Length of the } \\
\text { trident's medial } \\
\text { ossicle (=process) }\end{array}$ & $\begin{array}{l}\text { Length of the } \\
\text { trident's lateral } \\
\text { ossicle (=process) }\end{array}$ \\
\hline $\begin{array}{l}\text { M. socialis socialis } \\
\text { Kazakhstan, Emba }\end{array}$ & 5 & $\begin{array}{c}3.5 \\
3.25-3.70\end{array}$ & $\begin{array}{c}2.34 \\
2.20-2.50\end{array}$ & $\begin{array}{c}1.31 \\
1.10-1.50\end{array}$ & $\begin{array}{c}1.17 \\
1.00-1.35\end{array}$ & $\begin{array}{c}0.98 \\
0.75-1.10\end{array}$ \\
\hline \multirow{2}{*}{$\begin{array}{l}\text { M. s. nikolajevi } \\
\text { Ukraine, Crimea }\end{array}$} & 4 & $\begin{array}{c}4.06 \\
3.80-4.40\end{array}$ & $\begin{array}{c}2.59 \\
2.25-2.90\end{array}$ & $\begin{array}{c}1.54 \\
1.45-1.65\end{array}$ & $\begin{array}{c}1.48 \\
1.35-1.60\end{array}$ & $\begin{array}{c}1.13 \\
1.00-1.20\end{array}$ \\
\hline & $15^{\star}$ & $\begin{array}{c}3.99 \\
3.60-4.45\end{array}$ & $\begin{array}{c}2.59 \\
2.15-3.15\end{array}$ & $\begin{array}{c}1.37 \\
1.10-1.70\end{array}$ & $\begin{array}{c}1.22 \\
1.00-1.40\end{array}$ & $\begin{array}{c}1.01 \\
0.75-1.20\end{array}$ \\
\hline $\begin{array}{l}\text { M. s. binominatus } \\
\text { Georgia, Tbilisi }\end{array}$ & 19 & $\begin{array}{c}4.04 \\
3.65-4.40\end{array}$ & $\begin{array}{c}2.59 \\
2.25-2.75\end{array}$ & $\begin{array}{c}1.38 \\
1.10-1.65\end{array}$ & $\begin{array}{c}1.32 \\
1.10-1.55\end{array}$ & $\begin{array}{c}1 \\
0.85-1.25\end{array}$ \\
\hline $\begin{array}{l}\text { M. s. aristovi ssp. nov. } \\
\text { S-W. Azerbaijan }\end{array}$ & 4 & $\begin{array}{c}4.21 \\
4.00-4.40\end{array}$ & $\begin{array}{c}2.65 \\
2.60-2.75 \\
\end{array}$ & $\begin{array}{c}1.53 \\
1.20-1.70\end{array}$ & $\begin{array}{c}1.45 \\
1.20-1.60\end{array}$ & $\begin{array}{c}1.13 \\
1.05-1.25\end{array}$ \\
\hline $\begin{array}{l}\text { M. s. zaitsevi ssp. nov. } \\
\text { E. Azerbaijan }\end{array}$ & 3 & $\begin{array}{c}3.85 \\
3.60-4.10\end{array}$ & $\begin{array}{c}2.45 \\
2.30-2.60\end{array}$ & $\begin{array}{c}1.18 \\
1.15-1.25\end{array}$ & $\begin{array}{c}1.38 \\
1.30-1.45\end{array}$ & $\begin{array}{c}0.98 \\
0.80-1.10\end{array}$ \\
\hline $\begin{array}{l}\text { M. s. goriensis } \\
\text { Georgia, Tamarasheni }\end{array}$ & 11 & $\begin{array}{c}3.72 \\
3.40-4.00\end{array}$ & $\begin{array}{c}2.38 \\
2.15-2.50\end{array}$ & $\begin{array}{c}1.29 \\
1.10-1.60\end{array}$ & $\begin{array}{c}1.26 \\
1.15-1.45\end{array}$ & $\begin{array}{c}0.95 \\
0.85-1.05\end{array}$ \\
\hline $\begin{array}{l}\text { M. s. parvus } \\
\text { Russia, Stavropol Prov., Divnoye }\end{array}$ & 8 & $\begin{array}{c}4.03 \\
3.70-4.35\end{array}$ & $\begin{array}{c}2.58 \\
2.05-2.90\end{array}$ & $\begin{array}{c}1.49 \\
1.05-1.70\end{array}$ & $\begin{array}{c}1.25 \\
1.10-1.45\end{array}$ & $\begin{array}{c}0.86 \\
0.75-0.95\end{array}$ \\
\hline $\begin{array}{l}\text { M. s. parvus } \\
\text { Russia, Daghestan, Kaspiisk }\end{array}$ & 7 & $\begin{array}{c}3.97 \\
3.75-4.30\end{array}$ & $\begin{array}{c}2.52 \\
2.40-2.85\end{array}$ & $\begin{array}{c}1.36 \\
1.15-1.55\end{array}$ & $\begin{array}{c}1.33 \\
1.25-1.40\end{array}$ & $\begin{array}{c}0.94 \\
0.85-1.05\end{array}$ \\
\hline $\begin{array}{l}\text { M. s. gravesi } \\
\text { Kazakhstan, Baigara }\end{array}$ & 2 & $3.70,4.00$ & $2.50,2.70$ & $1.40,1.50$ & $1.20,1.30$ & $1.00,1.05$ \\
\hline $\begin{array}{l}\text { M. schidlovskii } \\
\text { Armenia, Talin }\end{array}$ & 5 & $\begin{array}{c}4.43 \\
4.15-4.80\end{array}$ & $\begin{array}{c}2.72 \\
2.25-2.90\end{array}$ & $\begin{array}{c}1.62 \\
1.40-1.80\end{array}$ & $\begin{array}{c}1.53 \\
1.35-1.90\end{array}$ & $\begin{array}{c}0.95 \\
0.75-1.20\end{array}$ \\
\hline \multirow{2}{*}{$\begin{array}{l}\text { M. paradoxus } \\
\text { Turkmenistan, Kopetdagh }\end{array}$} & 7 & $\begin{array}{c}4.52 \\
4.10-5.00\end{array}$ & $\begin{array}{c}3.32 \\
2.95-3.65\end{array}$ & $\begin{array}{c}1.72 \\
1.55-1.90\end{array}$ & $\begin{array}{c}0.99 \\
0.95-1.05\end{array}$ & $\begin{array}{c}0.97 \\
0.95-1.05\end{array}$ \\
\hline & $8^{*}$ & $\begin{array}{c}4.26 \\
4.00-4.75 \\
\end{array}$ & $\begin{array}{c}3.06 \\
2.70-3.60 \\
\end{array}$ & $\begin{array}{c}1.73 \\
1.55-1.95 \\
\end{array}$ & $\begin{array}{c}1.08 \\
0.95-1.10 \\
\end{array}$ & $\begin{array}{c}1.01 \\
0.95-1.10 \\
\end{array}$ \\
\hline $\begin{array}{l}\text { M. guentheri strandjensis } \\
\text { Bulgaria, Burgas Prov., Sozopol }\end{array}$ & 5 & $\begin{array}{c}4.43 \\
4.15-4.75\end{array}$ & $\begin{array}{c}3.15 \\
2.95-3.50\end{array}$ & $\begin{array}{c}1.92 \\
1.55-2.30\end{array}$ & $\begin{array}{c}1.24 \\
1.15-1.35\end{array}$ & $\begin{array}{c}1.08 \\
1.05-1.15\end{array}$ \\
\hline
\end{tabular}

* Data after Aksenova (1983). 

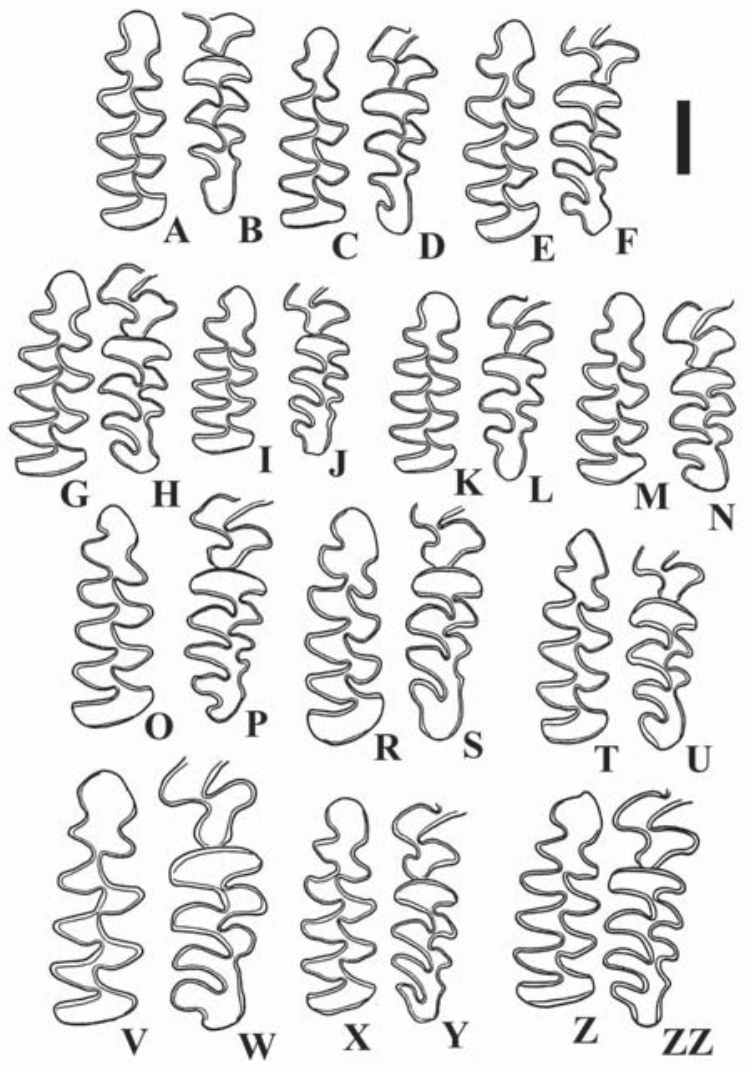
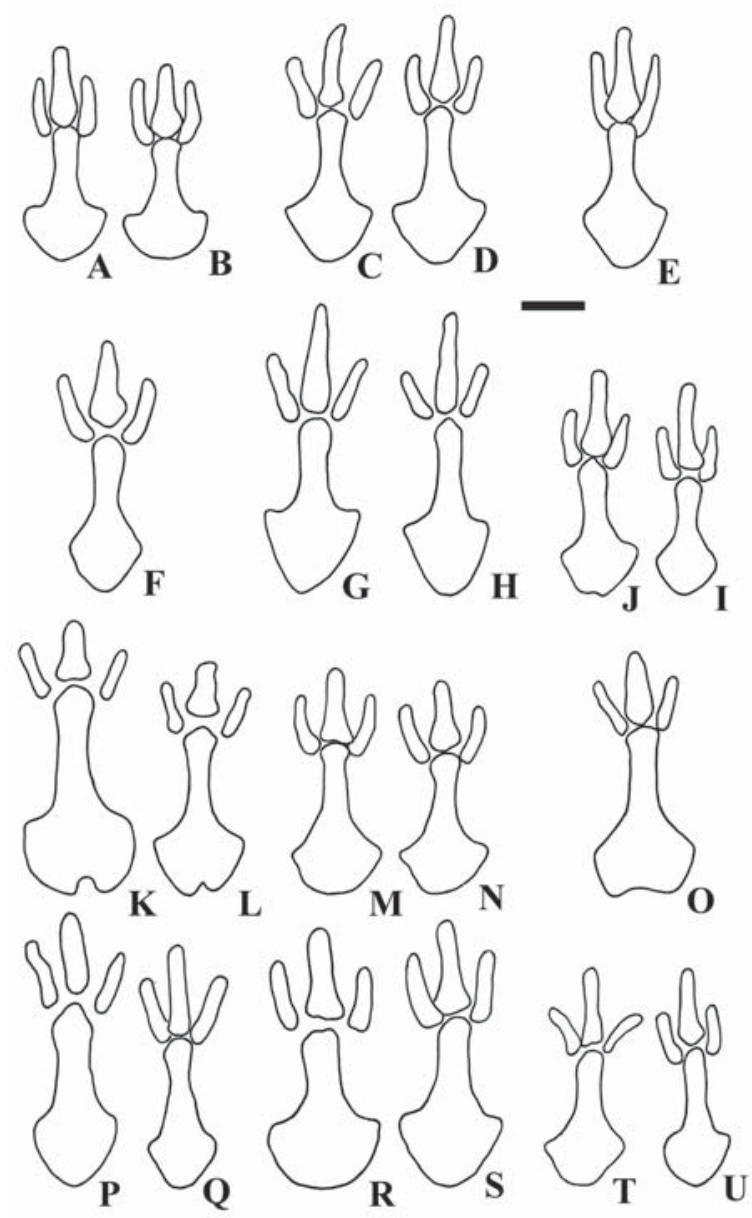

Figure 2. MOLARS OF THE SUMERIOMYS VOLES IN OCCLUSAL VIEW: m1 (A, C, E, G, J, K, M, O, R, T, V, X, AND Z) ANDm3 WITH POSTERIOR PORTION OF M2 (B, D, F, H, I, L, N, P, S, U, W, Y AND ZZ). Scale bar $1 \mathrm{~mm}$. A, B - M. s . socialis, ZIN 6806, Kazakhstan, vicinity of the Gur'ev city; C, D - M. s. nikolajevi, ZIN 77665, Ukraine, Kherson Province, Kuyuk-Tuk Island; E, F - M. s. binominatus, ZIN 77638, Georgia, vicinity of the Tbilisi city; G, H - M. s. goriensis, ZIN 78334, Georgia, Tamarasheni; I, J M. s. goriensis, ZIN 77661, Georgia, Tamarasheni; K, L-M. schidlovskii, ZIN 26070, Armenia, Nalband; M, N - M. s. parvus, ZIN 77683, Russia, Stavropol Province, Divnoye; O, $\mathrm{P}$ - M. paradoxus, ZIN 71302, Turkmenistan, vicinity of the Ashkhabad city, Dushak Mountain; R, S - M. paradoxus, ZIN 71780, Turkmenistan, vicinity of the Ashkhabad city, Dushak Mountain; T, U - M. s. gravesi, ZIN 57235, Kazakhstan, Betpakdala Steppe, Baigara; V, W - M. guentheri strandjensis, ZIN 80128, Bulgaria, Burgas Province, Sozopol; X, Y - M. s. zaitsevi ssp. nov., ZIN 72639, holotype, Azerbaijan, vicinity of the Baku city; Z, ZZ - M. s. aristovi ssp. nov., ZIN 37637, holotype, Azerbaijan, Veysalli.
Figure 3. BACULUM IN THE SUMERIOMYS VOLES. Scale bar $1 \mathrm{~mm}$. A, B - M. s. socialis, ZIN 49565 (A) and 49563 (B), Kazakhstan, Gur'ev Province, right bank of the Emba River; C - M. s. nikolajevi, ZIN 84926-2, Ukraine, Crimea, Kerch; D - M. s. nikolajevi, ZIN 84926-3, Ukraine, Crimea, Peschanoye; E - M. s. binominatus, ZIN 84925-35, Georgia, vicinity of the Tbilisi city; F - M. s. goriensis, ZIN 84923-58, Georgia, Tamarasheni; G, H - M. schidlovskii, ZIN 84922-31 (G) and 84922-25 (H), Armenia, Maralik; J, I - M. s.parvus, ZIN 84924-34 (I) and 84924-35 (J), Stavropol Province, Divnoye; K, L - M. paradoxus, ZIN 84916-257 (K) and 84916-256 (L), Turkmenistan, vicinity of the Ashkhabad city, Dushak Mountain; M, N - M. s. gravesi, ZIN $57076(\mathrm{M})$ and $57074(\mathrm{~N})$, Kazakhstan, Betpakdala Steppe, Baigara; O - M. guentheri strandjensis, ZIN 84905-205, Bulgaria, Burgas Province, Sozopol; P - M. s. zaitsevi ssp. nov., ZIN 72639, holotype, Azerbaijan, vicinity of the Baku city; Q - M. s. zaitsevi ssp. nov., ZIN 78872, paratype, Azerbaijan, Karachala; R - M. s. aristovi ssp. nov., ZIN 38209, paratype, Azerbaijan, Karyagino; S - M. s. aristovi ssp. nov., ZIN 38234, paratype, Azerbaijan, Lachin; T, U M. s. parvus, ZIN 84927-28 (T) and 84927-15 (U), Russia, Daghestan, Kaspiisk. 
the Betpakdala Steppe, Dzhambul Province of Kazakhstan, and undetermined social voles from some places in the Azerbaijan: vicinity of the Baku City and Karachala village (Eastern Azerbaijan) and Fizuli City and Lachin City (SouthWestern Azerbaijan). Altogether 80 bacula were investigated (Tabl. 2).

Altogether 24 metaphase chromosomes and 12 meiotic chromosomes cover-glass preparations were made from the bone marrow cells using the generally adopted methods (Ford \& Hamerton, 1956; Williams et al., 1971). G- and C-banding were performed according to Seabright (1971) and Sumner (1972) respectively.

The two preparations of synaptoneme complexes (SCs) were derived from the primary spermatocytes taken from the testes of an adult laboratory hybrid males were produced according to Chandley (1990); they were stained with the silver nitrate (Howell \& Black, 1980). The latter were examined and photographed with a JEM-100, Jeol, Japan electron microscope.

In the hybridization experiments 221 pairs of animals were involved in different combinations.

\section{Results and discussion}

\section{Morphology}

A quite detailed morphological description of different Sumeriomys voles was published previously (Argyropulo, 1933; Ognev, 1950; Zykov \& Zagorodnyuk, 1988), so in this paper only a brief information or additional details which concern mainly the anterior lower (m1), second upper (M2), and posterior upper M3 molars (Fig. 2) as well as the shape of os penis, are given (Fig. 3, Tab. 2). Preliminary data on baculum size and structure variation have been published previously (Golenishchev, 1999).

M. socialis socialis. Size small, head and body up to $95.5 \mathrm{~mm}$, in average $92.5 \mathrm{~mm}$. Pelage of upper surface ochraceous, tinted with pale-yellow; underparts lightgray, with a yellowish tinge; tail slightly bichromatic. Number of foot-corns $5 / 5$.

In comparison with other nominal forms of the subgenus $M$. s. socialis can be characterized by the comparatively small skull and auditory bullae, and narrow interorbital space. In $\mathrm{m} 1$ there are five prismatic folds from the lingual side and four folds from the labial side $(5 / 4)$. The anterior unpaired prismatic fold in $\mathrm{m} 1$ is relatively wide, the first pair of reentrant angles is of equal depth, and the first pair of prismatic folds is placed alternate to each other. M1 is without any additional cogs. In M2 an additional cog can be rarely present. M3 morphotype could be either $4 / 4$ or $4 / 3$. The morphotypes $4 / 3$ and $4 / 4$ differs in the number of the prismatic folds from the labial side, being three or four respectively. On the lingual side there are four prismatic folds in M3. Shaft and trident of baculum are smaller than in other forms examined. The broadened base of the baculum shaft is rounded in posterior part and its shoulders are slightly turned up.

M. s. nikolajevi specimens from six localities differ only a little from each other. This form is also small, head and body $89-92 \mathrm{~mm}$, in average $90.8 \mathrm{~mm}$. Pelage of upper surface pale-grayish, without an ochraceous tinge; underparts light gray, tinted with yellow; tail slightly bichromatic. Number of foot-corns $5 / 5$.

In the skull proportions this form is very close to the nominative one. The anterior unpaired loop of $\mathrm{m} 1$ is not wide and its first anterior fold is not deep, which gives an asymmetric appearance to the paraconid. M1-2 usually lack an additional cog. The predominate morphotype of M3 is 4/3; the morphotype 4/4 can be found very rarely. The baculum morphology for this subspecies was described by Aksenova (1983). Our data are in agreement with her description. The baculum is larger than in the nominative subspecies, mainly due to its more massive trident. According to our data the total baculum length and the length of trident's medial ossicle are statistically reliably greater, than in the nominative subspecies $(\mathrm{P}<0.01$ and $\mathrm{P}<0.05$ respectively). The shoulders of shaft's base are gently sloping, and the basal edge of the shaft is slightly stretched.

M. s. binominatus is larger than other subspecies. Head and body $98-111 \mathrm{~mm}$, in average $104.6 \mathrm{~mm}$. Pelage of upper surface more distinctly gray with pale tinge; undertaprs gray or light-gray; tail bichromatic.Specimens from the type locality have number of foot-corns $5 / 5$.

The skull is larger than in the subspecies listed above, with relatively large auditory bullae. In most specimens anterior folds in $\mathrm{m} 1$ are of equal depth. An additional cog could be rarely present in M2 and never in M1. The M3 morphotypes 4/3 and 4/4 are present with equal frequency. The total baculum length and the length of the baculum shaft are the same as in the previous subspecies and reliably longer than in M. s. socialis. The width of the shaft's base and the length of the trident's medial ossicle are reliably less than in $M$. s. nikolajevi $(\mathrm{P}<0.05)$. The shoulders of shaft's base are gently sloping; basal edge of the shaft is either rounded or stretched, the latter condition is more common, occurring in $73.7 \%$ of specimens.

M. s. goriensis is distinctly smaller than M. s. binominatus. Head and body no longer than $98 \mathrm{~mm}$. Pelage of the upper surface grayish-pale, with distinct ochraceous tinge; underparts light-gray; distinct border in coloration between upper and ground surfaces; tail bichromatic. Number of foot-corns $5 / 5$.

The skull proportions and molars dimensions are very similar to those in $M$. s. nikolajevi. The structure of $\mathrm{m} 1$ is the same as in M. s. binominatus. Differs from the latter subspecies by more frequently present an additional cog in M1-2. In some specimens this additional $\operatorname{cog}$ can be developed in an additional loop in the posterior side of M2. The baculum is relatively small, close in size to that in the nominative subspecies, but having somewhat greater total length $(\mathrm{P}<0.05)$. From the bacula in the nominative subspecies it differs also by slightly different shape, shoulders of the base are more gently sloping, the posterior edge of the shaft is more often stretched (in $62.5 \%$ of specimens). Baculum of this subspecies differs from that in M. s. binominatus, 
the geographically closest subspecies, in reliably lesser total and shaft's length $(\mathrm{P}<0.001)$. From the bacula in $M$. s. parvus it reliably differs by greater total length and shaft's base width and lesser trident's lateral ossicles $(\mathrm{P}<0.01 ; \mathrm{P}<0.05 ; \mathrm{P}<0.05$ respectively).

M. s. parvus is a relatively small-sized subspecies. Head and body not greater than $105 \mathrm{~mm}$. Pelage of upper surface grayish-pale, with yellowish tinge; underparts gray or light-gray; tail slightly bichromatic. Number of foot-corns $5 / 5$.

The skull is not wide and the auditory bullae are larger than in all the subspecies listed above, with exception of M. s. binominatus. An asymmetric paraconid in $\mathrm{m} 1$ resembles that in $M$. s. nikolajevi. An additional cog is rarely present in M2 and not found in M1. The prevailing morphotype of M3 is 4/3.

Baculum is of a medial size, resembles that in $M . s$. nikolajevi, though the lateral and medial ossicles of its trident are somewhat shorter than in the latter $(\mathrm{P}<0.001$ and $\mathrm{P}<0.05$ respectively). Shoulders of the shaft's base are gently sloping, its posterior edge is most often stretched (in $62.5 \%$ of specimens).

M. s. gravesi is a small-sized vole. Head and body up to $115 \mathrm{~mm}$. Pelage of its upper surface grayish-pale and very light, lighter than in other social voles; underparts light-gray; tail either monochromatic or slightly bichromatic. Number of foot-corns $5 / 5$.

The skull is very similar in proportions with that in M. s. binominatus. The skull is wider than in other subspecies $M$. socialis, auditory bullae are comparatively large. The structure of $\mathrm{ml}$ is typical for the voles of this group, with somewhat prevailing asymmetrical paraconid. An additional cog is sometimes present in M2 and never in M1. The wealth majority of specimens have the 4/3 morphotype of M3. Baculum is of a medial size, trident's ossicles are only slightly differs in length, shoulders of the shaft's base are gently sloping, posterior edge of the shaft's base is rounded.

M. schidlovskii is a vole of a small size. Head and body $99-118 \mathrm{~mm}$, in average $105.6 \mathrm{~mm}$. This species differs from all other social voles by much darker coloration. Back grayish-brown; underparts gray or lightgray with yellowish tinge; tail bichromatic. Number of foot-corns $5 / 5$.

The skull is more flattened and broadened than in all the other voles of the subgenus, auditory bullae are small. Anterior unpaired loop of $\mathrm{m} 1$ is wide, the first anterior lingual prismatic fold and the first labial one are set up almost opposite to each other. An additional cog rarely occurs in M2 and absent in M1. The main morphotypes of M3 are $4 / 3$ and $4 / 4$, although the archaic morphotype $3 / 3$, which is not recorded in all the other forms of the subgenus, can be rarely observed. Baculum is large, in contrast to all the other social voles, the shoulders of its broadened base are distinctly turned up, being almost perpendicular to the shaft. Medial ossicle of the trident is longer than the lateral ones. The shaft's broadened base is stretched, its posterior edge is without a cutting. It reliably differs from baculum in $M . s$. binominatus, the closest geographic race, by greater total length, longer trident's medial ossicle, and greater width of the shaft's base $(\mathrm{P}<0.005, \mathrm{P}<0.05, \mathrm{P}<0.005$ respectively).

$M$. paradoxus distinctly differs by some characters from all the other voles of the subgenus Sumeriomys (Ogneff \& Heptner, 1928; Zykov \& Zagorodnyuk, 1988). It is a large vole, close to M. guentheri in body dimensions. Head and body up to $135 \mathrm{~mm}$, in average 116.5 . Pelage of upper surface grayish-pale, with a distinct yellowish tint; underparts either light-gray or whitish; tail either monochromatic or slightly bichromatic. Number of foot-corns usually $6 / 6$, sometimes $5 / 5$.

The skull is massive and broad, larger than in all the other species of the subgenus, with exception of $M$. guentheri. The brain-case is inflated. The auditory bullae are comparatively small. The anterior unpaired loop of $\mathrm{m} 1$ is broad, the first pair of prismatic folds are most often set up accumbently, the first prismatic labial fold being somewhat smaller than the lingual one. M1 usually has a additional cog, which in some specimens can be transformed into a loop. M2 always with an additional loop. Baculum is large, owing to its massive shaft. There is a well marked median cutting in the posterior edge of the shaft's broadened base. The medial ossicle of the trident is short, its length is equal to that of the lateral ones (Fig. 3K, L; Tab. 2). M. paradoxus reliably differs by all baculum characters, except the length of trident's lateral ossicles, from other known representatives of the subgenus.

The similar description of baculum in $M$. paradoxus was made by Aksenova (1983). Didier (1954) presented a detailed description of a baculum belonging to some social vole from Iran, which also possessed a medial cutting of the shaft's base. However, in contrast to that of $M$. paradoxus, it has more sloping guentheri-like shoulders. Unfortunately, Didier did not mention the geographic locality where the specimen had been collected, and thus, taking into consideration a high diversity of Iranian social voles (Golenishchev et al., 1999), this specimen cannot be attributed to $M$. irani.

M. guentheri strandjensis is a big vole. Head and body up to132 mm, in average $123.7 \mathrm{~mm}$. Back ochraceous-gray, darker than in other social voles with exception of M. schidlovskii; body and head sides with prominent reddish tinge; underparts light-gray; tail slightly bichromatic. Number of foot-corns $5 / 5$.

In the skull the brain-case is strongly inflated, the rostrum is high, the auditory bullae are small. The anterior unpaired loop of $\mathrm{m} 1$ is broad, the first anterior labial fold is usually not deep. An additional cog may be presented sometimes in M2 and absent in M1. In the morphotype $4 / 3$ is predominate. The baculum is large, resembling that of $M$. paradoxus, but having more gently sloping shoulders and longer trident's ossicles $(\mathrm{P}<0.001$ for the medial, and $\mathrm{P}<0.005$ for the lateral ones). A medial cutting of the shaft's basal edge is present, but less distinct than in M. paradoxus.

The social voles inhabited the South-Eastern Transcaucasia down to the cost of the Caspian Sea, are of a particular interest. They are usually referred to the $M . s$. 
binominatus (Ognev, 1950; Gromovetal., 1963), though their upper pelage is lighter than in that subspecies. The most light voles occur in the Eastern Azerbaijan in the vicinity of Baku City. Their back light, grayish-pale, with yellowish tinge more prominent than grayish; underparts light-gray with, slightly yellowish; tail monochromatic.

The social voles from the Eastern Azerbaijan are quite similar to $M$. s. binominatus in the shape of skull and size of molars, though their auditory bullae are larger. The majority of Transcaucasian specimens possess a distinctly developed additional cog in M1-2, which is transformed sometimes into an additional loop (Fig. 2Y). The baculum is somewhat smaller than inM. s. binominatus, with a comparatively narrow base and a short trident. The shoulders of the base are gently sloping (Fig. 3P, Q).

The social voles from the South-Western Azerbaijan are somewhat darker. They differ from the Eastern Azerbaijanian form also in a larger skull and auditory bullae, the latter being the largest within the subgenus. An additional cog is rarely present in M2 (Fig. 2ZZ) and absent in M1. The baculum has the same length as in M. $s$. binominatus, but has a more massive appearance due to a wider baculum shaft. The shoulders are turned up as in M. schidlovskii, the posterior edge of the shaft is rounded (Fig. 3R, S).

According to Argyropulo (1933), the social voles of the Moghan Steppe in the Eastern Azerbaijan also have a baculum with the rounded shaft's base. The social voles from the vicinities of Kaspiisk in Daghestan, which are referred by some authors (Akhverdyan, 1989) to M. s. binominatus, are quite similar to $M . s$. parvus in the pelage coloration, but distinct in occasional occurring of six foot-corns either in both foot (in $9.0 \%$ of the individuals examined) or in one of the feet (in 15.4\%). The baculum is also similar to that in M. s. parvus (Fig. 3T, U).

In general, the material from different regions is quite variable. For instance, one of the social voles (ZIN 38933) from the neighborhood of the Elton Lake, Volgograd Province, is quite similar to $M$. paradoxus in shape of its skull and molars, while all the other specimens collected from that locality look as a typical $M$. socialis. Also quite a morphologically distinct population inhabits the region of the Alacol' Lake in the Eastern Kazakhstan. In this form the skull is much wider than in M. s. gravesi, the auditory bullae are comparatively large. M1-2 lack an additional cog. This form is geographically adjacent to the range of $M$. s. bogdoensis Wang et Ma 1982, described from the foothills of the Bogdo Range in North-Western China. The latter is known to be the most eastern subspecies of $M$. socialis that has been ever found. The length of tail was considered as the main feature distinguishing between $M . s$. bogdoensis and M. s. gravesi (Wang \& Ma, 1982). In the

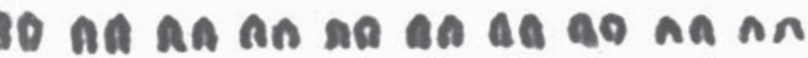

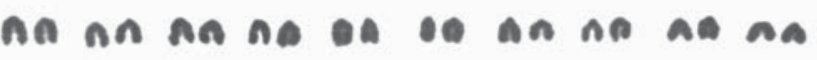

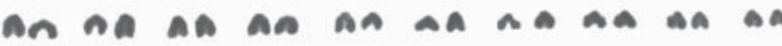
ค ค A

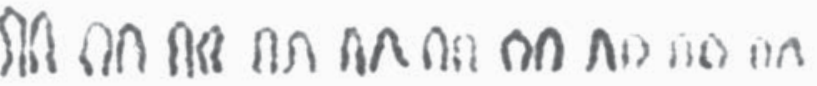

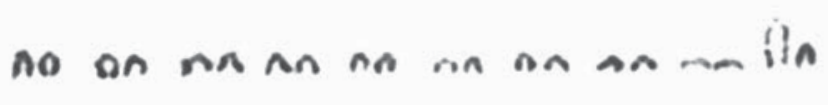

B

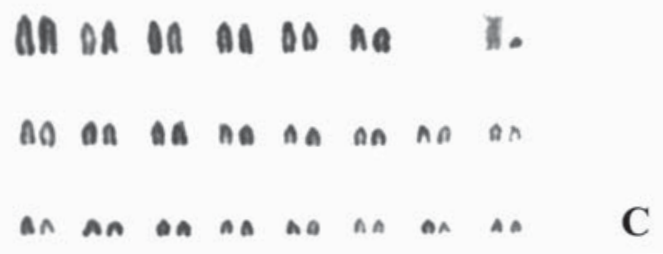

Figure 4. KARYOTYPES IN THE SUMERIOMYS VOLES (TOTAL STAINING). A - M. s. binominatus, O'; B - M. schidlovskii, ; $\mathrm{C}-M$. guentheri, , .

Chinese subspecies the tail is longer than $25 \mathrm{~mm}$. But, according to our data, in $M$. s. gravesi, quite often, the tail can also be longer than $25 \mathrm{~mm}$.

The frequency of occurrence and extent of expression of an additional cog in M1-2 increase from the Crimea and South-Eastern part of the European Russia to the Turkmenistan. For instance, in the Crimea, Kherson Province, circum-Azov Sea region, and Northern Caucasus only single individuals with an additional cog, being present only in M2, were recorded. In the Transcaucasian M. $s$. goriensis and in the Eastern Azerbaijanian social voles this cog can be present on both M1 and M2, sometimes being transformed into an additional loop. On the other hand, in the social voles inhabiting to the East from Turkmenistan, these characters are again less frequent.

\section{Description of karyotypes}

The karyotype in M. socialis (M. s. nikolajevi, M. s. binominatus, M. s. goriensis, M. s. parvus) and $M$. paradoxus contains 62 chromosomes (Fig. 4A). The diploid number of chromosomes in M. schidlovskii is 60 (Fig. 4B), and in M. guentheri is 54 (Fig. 4C). 


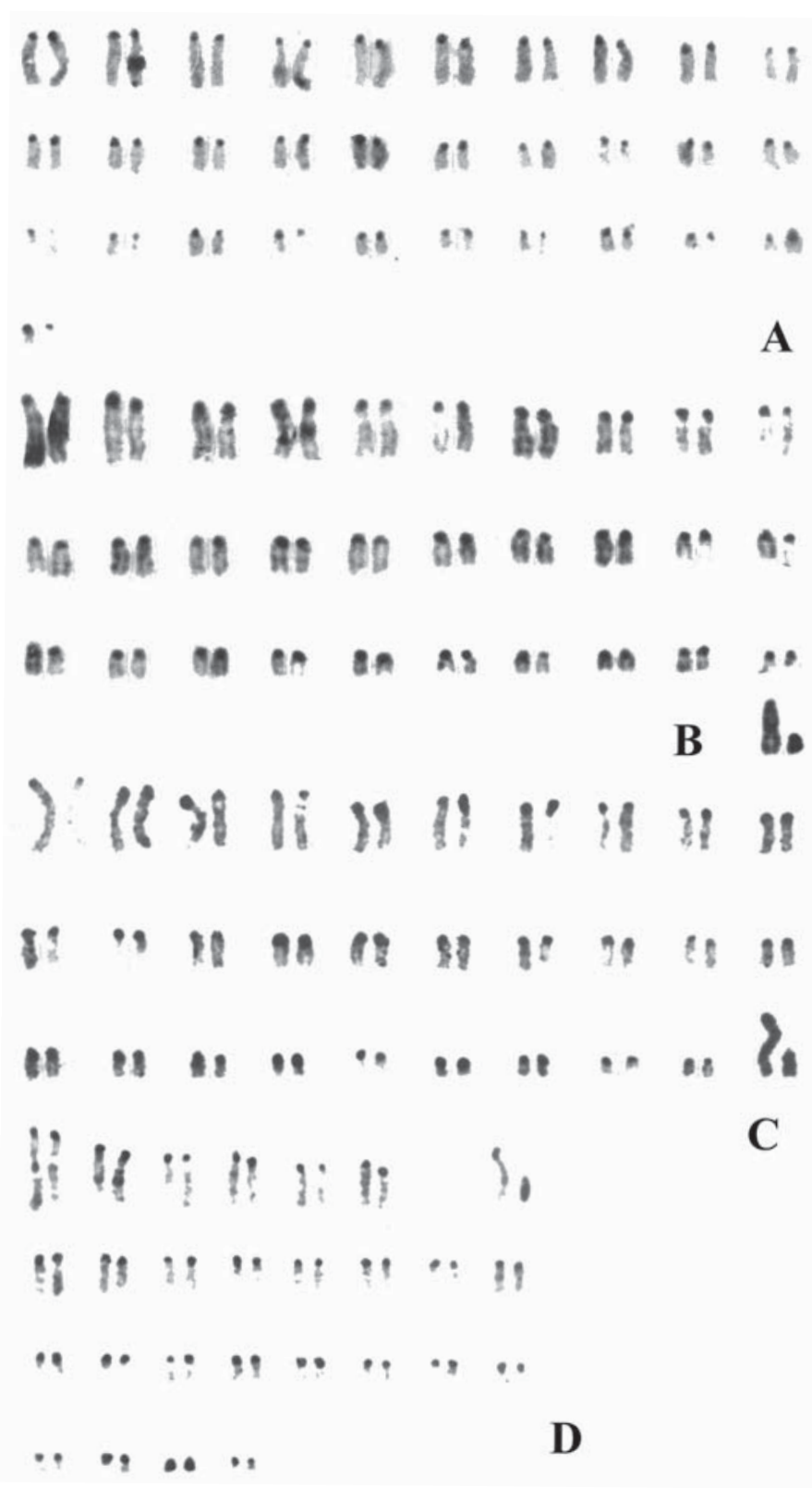

Figure 5. C-BANDED CHROMOSOMES IN THE SUMERIOMYS VOLES. A - M. s. binominatus, $\mathrm{O}^{7}$; B - M. paradoxus,, ; C $-M$. schidlovskii, ㅇ; D-M. guentheri, ㅇ.

All the chromosomes in $M$. socialis and $M$. paradox$u s$, including the sexual ones, are acrocentrics of decreasing size. $X$-chromosome is large, and $Y$ is comparatively small. Only in M. schidlovskii the first pair of autosomes is distinctly larger than the others. In $M$. guentheri all the autosomes and the $Y$-chromosome are also acrocentrics, and $X$-chromosome is subtelocentric. The detailed description of the karyotype for the Guenther's vole, was published by Belchevaet al. (1980). Our data agrees with that description.

In all karyotypes examined heterochromatin is presented as small slightly stained precentromeric blocks in autosomes and $X$-chromosome. $Y$-chromosome is com- pletely heterochromatic (Fig. 5A-D). All the pairs of G-banded autosomes and sexual chromosomes are distinctly visible (Figs. 6-8). The karyotypes of M. s. nikolajevi, M. s. binominatus, M. s. goriensis, M. s. parvus and M. paradoxus found to be identical. We show here (Fig. 6A) karyotypes of only two of these forms, $M$. s. binominatus(Talysh Mountains, Azerbaijan) and $M$. paradoxus. Comparative analysis of Gbanded chromosomes revealed the only karyotypic difference between $M$. socialis (exemplified by M. s. nikolajevi) and M. schidlovskii: the first (the largest) autosome of M. schidlovskii corresponds with two fused autosomes of $M$. socialis (the largest and the smallest ones). All the other chromosomes of both of the species, including the sexual ones, are identical. According to Akhverdyan (1989), in the Western Armenia the diploid number of chromosomes in some individuals of $M$. schidlovskii is 62 , instead of 60 . That aberrant karyotype is supposed to be identical to that in $M$. socialis.

Comparison of G-banded chromosomes in M. socialis and M. guentheri (Fig. 8) showed that their karyotypes differ from each other in at least four tandem fusions: in three cases one autosome of $M$. guentheri corresponds with two fused autosomes of $M$. socialis and, on contrary, one of the autosomes of $M$. socialis corresponds with two fused ones of $M$. guentheri. Those fusions are as follows: G1 chromosome corresponds with S1 and S16 ones, G2 with S14 and S27, G22 with S28 and S30, $\mathrm{S} 2$ with $\mathrm{G} 4$ and $\mathrm{G} 26(\mathrm{G}$ - chromosomes of $M$. guentheri, $\mathrm{S}$ - chromosomes of M. socialis). The electron microscopic analysis of meiosis in hybrids between those two forms showed up to four trivalents. This confirms the differences between karyotypes in these forms, which had been revealed by G-band staining.

Five pairs of autosomes in the $M$. socialis karyotype, being identical to the corresponding ones of $M$. guentheri in the G-band pattern, differ from them in position of centromere. They are G3 and S3, G4 and S2, G11 and $\mathrm{S} 12, \mathrm{G} 13$ and S11, G16 and S13. All the other autosomes and sexual chromosomes in both of the forms are identical. For two small autosomes (24 and 29 ) in the karyotype of $M$. guentheri the elements corresponding with that of $M$. socialis have not been found. It could be explained by difficulties in identification of so small elements. It should be mentioned, that owing to the same reason, the chromosomes S27, S28 and S30, when being involved in tandem fusions, were recognized quite conventionally. In the diakinesis of $M$. socialis 30 autosomal bivalents with one-two chiasmas were observed (Fig. 9A). The sexual chromosomes are not always completely paired. 


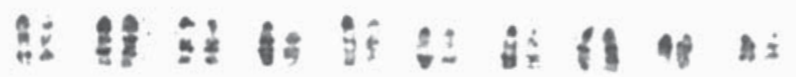

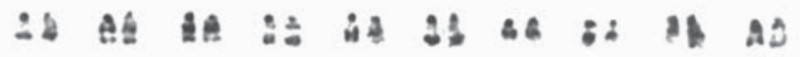

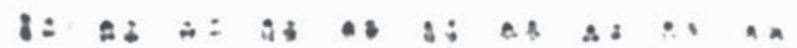

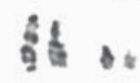
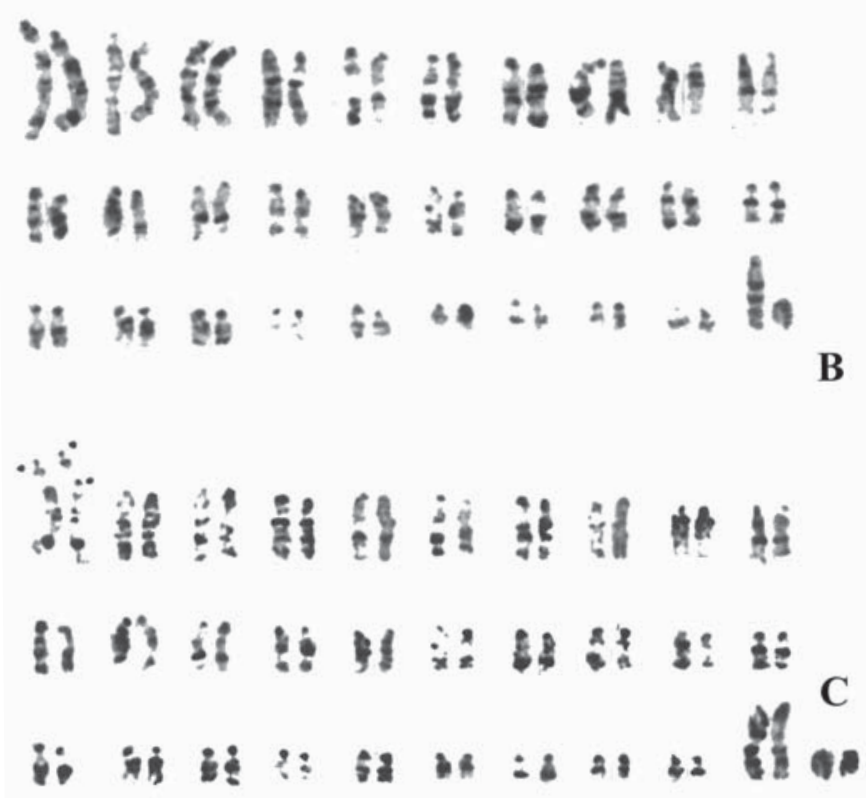

Figure 6. G-BANDED CHROMOSOMES IN THE SUMERIOMYS VOLES. CENTROMERES ARE MARKED WITH DOTS. A - chromosomes of $M$. s. binominatus,, , being compared with those of $M$. paradoxus, + (in each pair of chromosomes the right one belongs to $M$. s. binominatus, and the left one to M. paradoxus); B - karyotype of $M$. schidlovskii, + ; C - chromosomes of M. s. nikolajevi, + , being compared with those of M. schidlovskii, $\rightarrow$ (in each pair of chromosomes the right one belongs to $M . s$. nikolajevi, and the left one to $M$. schidlovskii).

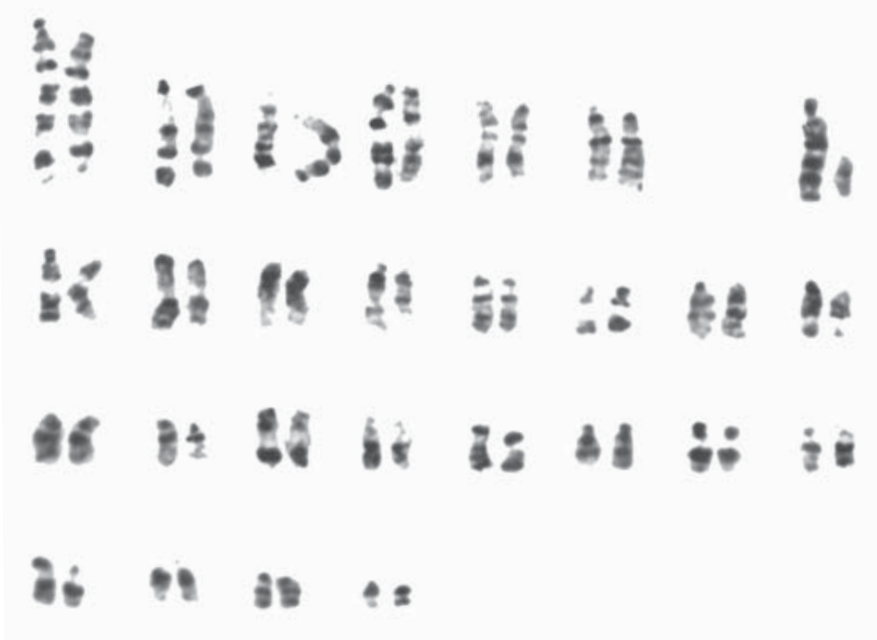

Figure 7. KARYOTYPE OF M. GUENTHERI, ๆ (G-BANDING).

\section{Hybridization}

The hybrids between the four studied subspecies of $M$. socialis as well as between each of them and $M$. paradoxus in all the combinations of intercrossing were being obtained quite easily and showed a normal postnatal development. However, the fertility of intercrossed non-conspecific partners occurred to be decreased. Moreover when having a free choice the individuals of both sexes distinctly prefer copulating with conspecific partners (Zorenko et al., 1997).

The hybrids of both sexes between M. guentheri and any other studied form of the subgenus were sterile. Among the hybrids between M. schidlovskii and each of the forms studied, with exception of $M$. guentheri, only males occurred to be sterile, while the females revealed a normal fertility. In the diakinesis of those hybrid males we find 28 normal autosomal bivalents, one trivalent and either partially or completely unpaired sexual chromosomes (Fig. 9B). This observation is in accordance with an earlier one (Akhverdyan, 1989). However, we found also four univalents in the later stages of metaphase II in those hybrid males. We suppose it to happen owing to premature dissociation of some two bivalents. Possibly, this is responsible for the sterility of hybrid males.

In the Fig. 10A, B some spermatocyte cells of M. s. binominatus, M. schidlovskii and $M$. guentheri shown at the stage of a medial pachytene. The pairing of all the autosomes was normal. The sexual chromosomes approached each other but did not conjugate. The latter phenomenon had also been known for some other representatives of the genus Microtus (Ashley et al., 1989; Borodin et al., 1991).

In the pachytene cells of hybrids produced in interbreeding of $\sigma^{\top} M$. s. binominatus $\mathrm{x}+M$. schidlovskii one trivalent was observed (Fig. 10D). In that trivalent the complete pairing between each of the arms of the biarmed autosome and consequent homologous acrocentrics can be observed. Sometimes the precentromeric regions were left unpaired, but more often they are completely paired with each other. Such a kind of pairing within the robertsonian trivalents had already been described for some rodents and insectivores (Borodin, 1991; Borodin et al., 1991).

In the hybrids between $\sigma^{7} M$. guentheri and q M. s. binominatus, which are heterozygous in a number of chromosomal rearrangements, the synapsis of chromosomes occurred to be hampered. The majority of cells possess 3-4 robertsonian trivalents with a lengthy precentromeric regions of asynapsis. The univalents and non- 


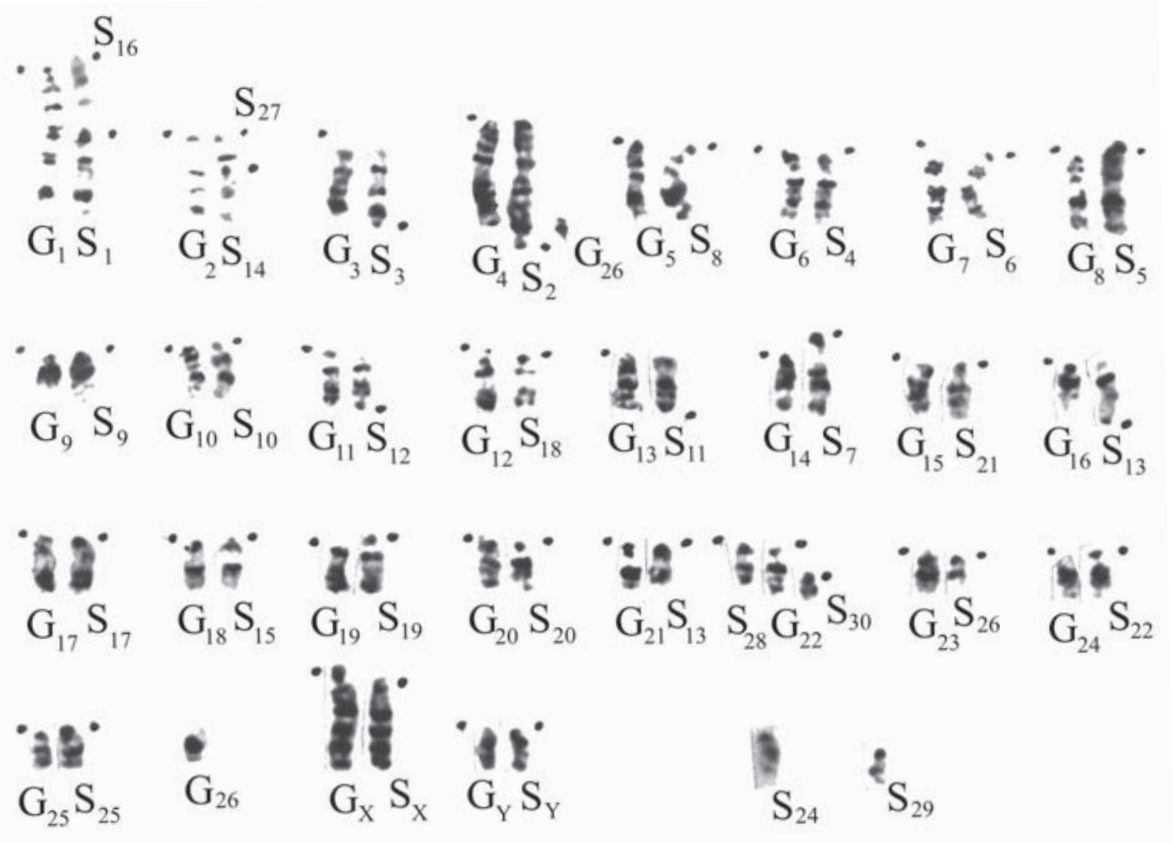

Figure 8. CHROMOSOMES (G-BANDING) OF M. GUENTHERI, + , BEING COMPARED WITH THOSE OF $M$. SOCIALIS, ㅇ $(\mathrm{G}-M$. guentheri, $\mathrm{S}-\mathrm{M}$. socialis). Centromeres are marked with dots.
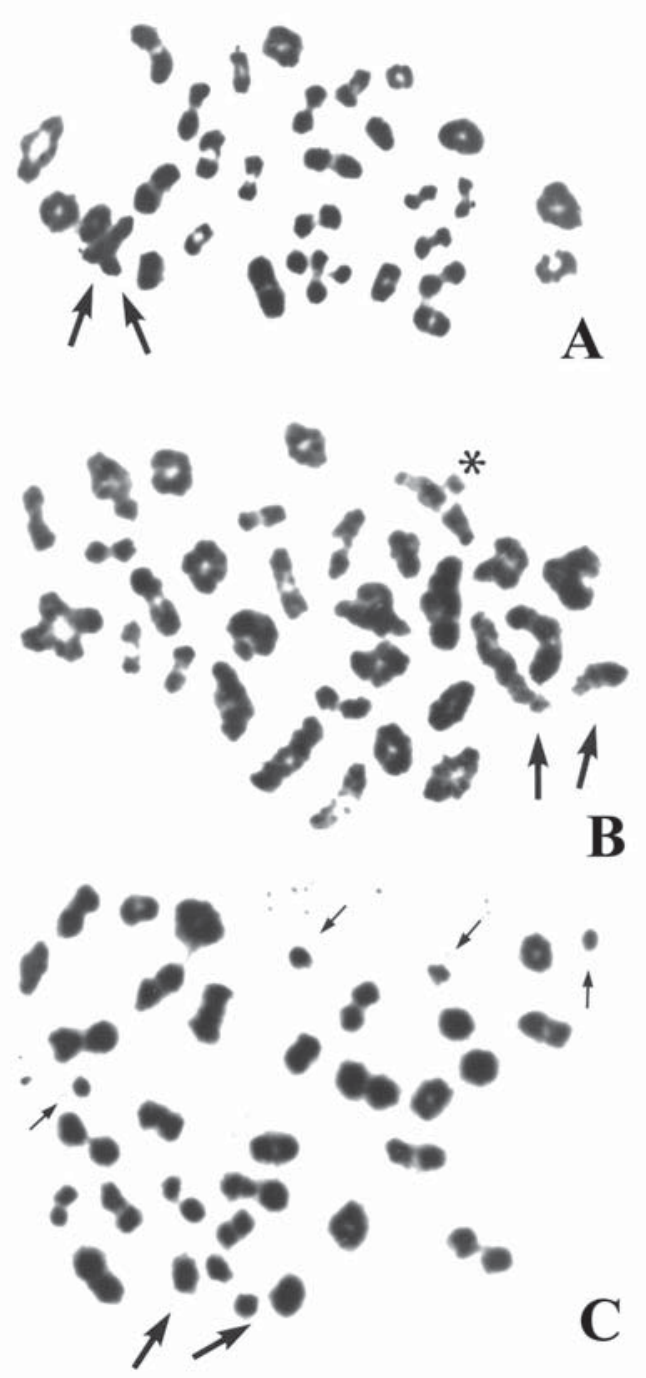

homologous pairing of chromosomes were also quite often observed in the hybrids (Fig. 10E). The abnormal meiosis and sterility of masculine hybrids between $M$. schidlovskii and $M$. socialis of any intercrossing combination suggests those nominal forms to be distinct species within the subgenus Sumeriomys.

The hybrids between all the studied 62 chromosomal nominal forms occurred to be fertile and possessed a normal pattern of meiosis. It also concerns M. s. nikolajevi and $M$. paradoxus, in spite of their considerable geographic remoteness from each other. We suppose that Zykov \& Zagorodnyuk (1988) failed to obtain hybrids between those two subspecies only because of the insufficient number of experiments and/or of some unfavorable conditions. There is no doubt about the specific distinctness of M. schidlovskii, because this is advocated not only by experiments on hybridization but also some morphological data discussed above.

Concerning the taxonomic status of $M$. paradoxus, this question does not seems to be so easy, taking into consideration the fertility of hybrids between that form and all the subspecies ofM. socialis. However, the lower fertility of $M$. paradoxus, when being intercrossed with other social voles of the same karyotype, as well as their reliably evident mating choice in favor of the native sexual partners (Zorenko et al., 1997) suggest that it could be an independent species. Moreover, M. paradoxus shows significant differences from all the studied subspecies of M. socialis in size and shape of skull, molars and baculum.

Figure 9. METAPHASE I OF MEIOSIS IN THE MALES OF THE SUMERIOMYS VOLES AND THEIR HYBRIDS (sexual chromosomes are marked with long arrows, univalents with short arrows, trivalents with asterisks). $\mathrm{A}-M$. paradoxus; $\mathrm{B}, \mathrm{C}-\mathrm{F} 1$ hybrid between $\bigcirc^{\top}$ M. paradoxus $\mathrm{x}+$ 9 . schidlovskii. 

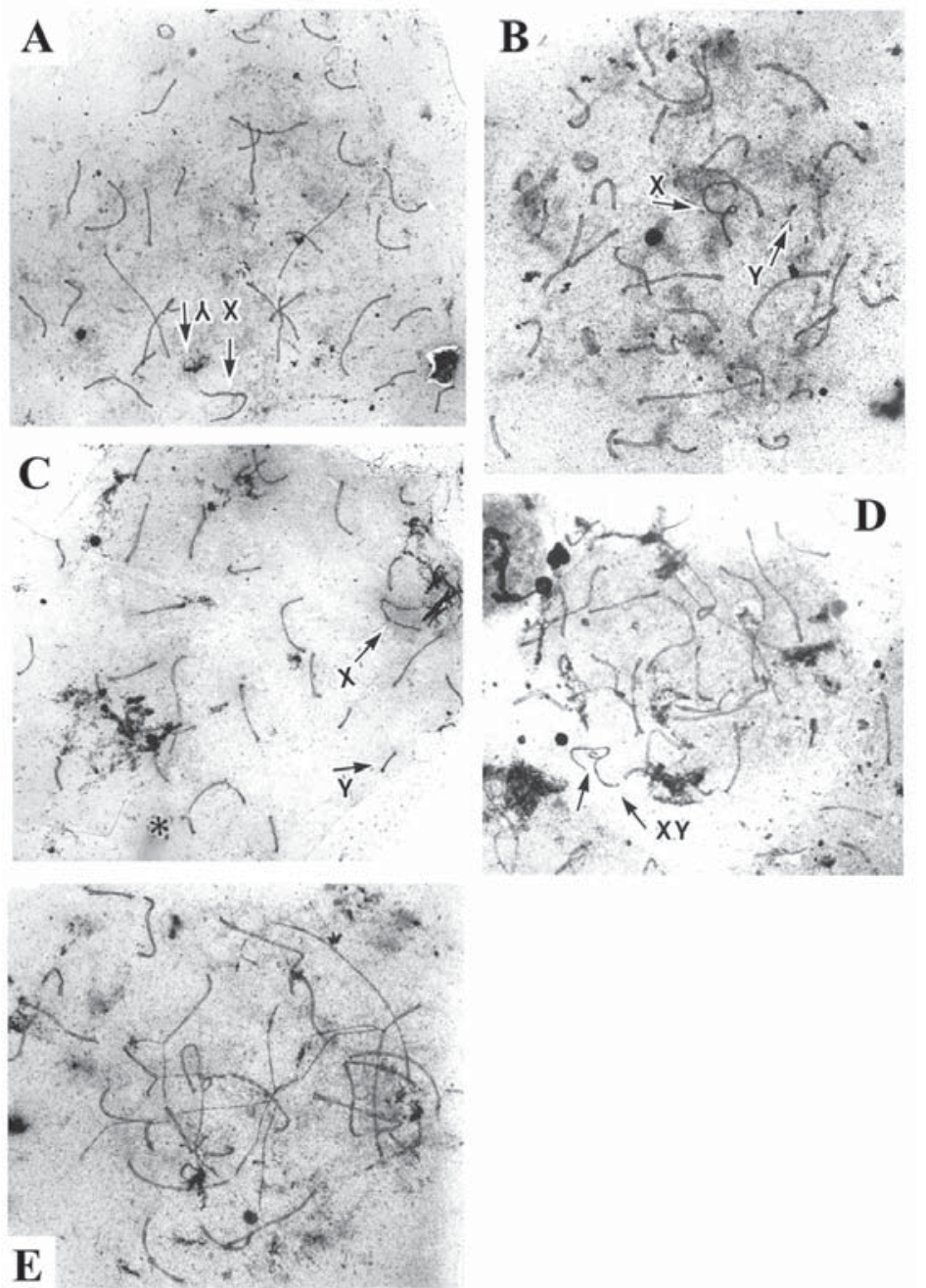

Figure 10. SYNAPTONEMAL COMPLEXES IN SPERMATOCYTE CELLS OF PURE FORMS AND THEIR HYBRIDS (sexual chromosomes are marked with arrows, trivalents with asterisks). A - M. s. binominatus; B - M. schidlovskii; C - M. guentheri; D - hybrid F1 ( $\sigma^{7}$ M. s. binominatus $\mathrm{x}+$ M. schidlovskii), translocation trivalent; $\mathrm{E}$ - hybrid F1 ( $\sigma^{\top}$ M. guentheri $\mathrm{x}+$ M. s. binominatus), multiple breach of synapsis.

Microtus (Sumeriomys) schidlovskii Argyropulo, 1933 - the Schidlovski’ vole.

=Microtus (Sumeriomys) colchicus schidlovskii: Argyropulo, 1933: S.182.

Holotype - ZIN 26048, adult female (skin and skull). Vicinity of Nalband railway station, $35 \mathrm{~km}$ E from Leninakan, Armenia. Collectors A.I. Argyropulo and N. Podgornov, 9/VI 1932.

Paratypes - ZIN 26043-26047,26049-26056, 26058, 26059, 26061-26070, 26129-26131 (altogether 28 specimens). Locality and collectors as for the holotype.

DIAGNOSIS. Back dark, gray-brown. Underparts dark-gray. Adults with a prominent ochraceous stripe on sides between back and belly coloration. Tail bichromatic. Ground surface of feet dark. In contrast to other voles of subgenus, on volar and plantar finger surfaces there is a pattern of alternating light and dark rings, formed by corneous scales. Head and body up to $118 \mathrm{~mm}$, tail $25-34 \mathrm{~mm}$, foot 14.0 $16.5 \mathrm{~mm}$. M2 rarely possesses small additional $\operatorname{cog}$ at its postero-lingual side. Baculum large, differing from that in other social voles by turned up shoulders of shaft's base, comparatively long trident's medial ossicle, and short lateral ones. Posterior edge of shaft's base without a cutting (Fig. 3G, H).Total baculum length 4.10-4.25 mm, shaft length 2.80-2.95 $\mathrm{mm}$, width of shoulders $1.35-1.45 \mathrm{~mm}$, trident's medial ossicle 1.55-1.70 mm, lateral ossicles 1.15-1.25mm. Diploid number of chromosomes $2 \mathrm{n}=60$.

DISTRIBUTION. Western Armenia.

Microtus socialis aristovi Golenishchev ssp. nov.

Holotype - ZIN 37637, adult male (skin and skull). Vicinity of Veisalli, Fizuli District, Azerbaijan. Collector H.M. Alekperov, 15/II 1953.

Paratypes - ZIN 38209, male in alcohol (baculum). Locality as for the holotype. Collector H.M. Alekperov, VIII 1952; ZIN 38234, male in alcohol (baculum). Vicinity of the Lachin City, Azerbaijan. Collector H.M. Alekperov, 1953

DIAGNOSIS. Back darker than in geographically close $M$. s. binominatus, but considerably lighter than in M. schidlovskii. Skull

\section{Taxonomy}

The composite taxonomic analysis presented here confirm the specific status for M. schidlovskii that has been established earlier by Akhverdyan et al. (1991a). We accept also the idea of Zykov and Zagorodnyuk about the species status for the M. paradoxus. Herein the revised diagnosis is given for only $M$. schidlovskii. The complete diagnosis for $M$. paradoxus was provided by Zykov \& Zagorodnyuk (1988).

Two geographic forms of $M$. socialisfrom the SouthEastern Transcaucasia are described here as new subspecies. with particularly large auditory bullae. An additional $\operatorname{cog}$ is rarely present in M2 (Fig. 2ZZ) and absent in M1. Baculum as long as in $M$. s. binominatus, but has a more massive appearance due to broadened shaft and base. Total baculum length $4.20-4.30 \mathrm{~mm}$, width of shoulders $1.55-1.70 \mathrm{~mm}$, trident's medial ossicle $1.45-1.55 \mathrm{~mm}$, trident's lateral ossicles 1.10 $1.15 \mathrm{~mm}$. Shoulders of shaft's base are turned up as in $M$. schidlovskii, posterior edge of the shaft's base is rounded (Fig. 3R, S)

DISTRIBUTION. South-Western Azerbaijan, Nakhichevan', Eastern Armenia.

ETYMOLOGY. The new subspecies is named after late Dr. Alexei A. Aristov, the scientist of the Laboratory of Theriology, Zoological Institute RAS, who for many times participated in collecting the material on social voles in the field during our joint expeditions. 


\section{Microtus socialis zaitsevi Golenishchev ssp. nov.}

Holotype - ZIN 72639, adult male (body in alcohol and skull in dry collection, os penis kept separately). Vicinity of the Baku City (airport), Azerbaijan. Collector M.V. Zaitsev, 16/VIII 1985.

Paratypes - ZIN 78871-78875, five adult specimens (dry skulls preserved in alcohol). Near Karachala City, Azerbaijan. Collector K.A. Satunin, 25-30/IX 1914.

DIAGNOSIS. Back lighter than in other subspecies, similar to that in M. paradoxus. Most close to M. s. binominatus in shape of skull and size of molars, but differs from the latter by larger auditory bullae, which are, smaller, however, than in M. s. aristovi ssp. nov. An additional cog is present in most specimens of both M1 and M2, being transformed sometimes into loop (Fig. 2Y). Baculum shorter and thinner than in M. s. aristovi ssp. nov., with narrower shaft's base and comparatively short trident's ossicles. Total baculum length 3.60 $4.10 \mathrm{~mm}$, width of shoulders $1.15-1.25 \mathrm{~mm}$, trident's medial ossicle $1.30-1.45 \mathrm{~mm}$, lateral ossicles $0.80-1.10 \mathrm{~mm}$. Shoulders of shaft's base are slanting (Fig. 3P, Q).

DISTRIBUTION. Eastern part of Azerbaijan adjacent to the coast of the Caspian Sea.

ETYMOLOGY. The new subspecies is named after Dr. Mikhail V. Zaitsev, the scientist of the Laboratory of Theriology, Zoological Institute RAS, who collected a valuable material on the Caucasian forms of M. socialis.

On the base of the data on the baculum structure presented in this report we provide identification keys for the voles of the subgenus Sumeriomys.

1(4). Medial trident's ossicle is less than $1.35 \mathrm{~mm}$, posterior edge of shaft's base with a medial cutting.

2(3). Medial trident's ossicle is less than $1.20 \mathrm{~mm}$, a medial cutting at the posterior edge of shaft's base is prominent (Fig. 3K, L) ............................................. paradoxus.

3(2). Trident's medial ossicle is more than $1.20 \mathrm{~mm}$, a medial cutting at the posterior edge of shaft's base is less prominent (Fig. 30) ......................................... M. guentheri.

4(1). Trident's medial ossicle is more than $1.35 \mathrm{~mm}$, the posterior edge of shaft's base is without a medial cutting.

5(6). Trident's medial ossicle is more than $1.70 \mathrm{~mm}$, shoulders of shaft's base are steep, almost perpendicular to the baculum vertical axis (Fig. $3 \mathrm{G}, \mathrm{H}$ ) ........ M. schidlovskii.

6(5). Trident's medial ossicle is less than $1.70 \mathrm{~mm}$, the shoulders of shaft's base are gently sloping (Fig. 3A-F, J, $\mathrm{I}, \mathrm{M}, \mathrm{N}, \mathrm{P}-\mathrm{U})$ M. socialis.

\section{Conclusions}

The results of our taxonomic revision are in accordance with the idea of Ellerman (1941) about two species groups within the subgenus Sumeriomys, which are "socialis" (M. socialis, M. paradoxus, and M. schidlovskii) and "guentheri" (M. guentheri). In general, voles of the "socialis" group show that chromosomal rearrangements can lag behind the morphological evolution. Such a situation is not typical to the genus Microtus.

The forms with a close or even identical karyotypes (M. schidlovskii, $2 \mathrm{n}=60$ and all the forms with chromosomes of $M$. socialis, $2 \mathrm{n}=62$ ) quite differ from each other in body size, pelage coloration, presence of an additional cog in M1-2, including the extent of its development, size and shape of baculum. All the subspecies of $M$. socialis are practically allopatric. That is why their reproductive isolation can be tested only in the laboratory. Our experiments on hybridization of subspecies considered showed a lack of post-copulating reproductive isolating mechanisms. However, the decreased fertility of mixed couples gives an evidence of initial stages of pre-copulating reproductive isolation (Zorenko et al., 1997).

The composition of the "guentheri" group is still in question. On the one hand, the karyotype of M. g. guentheri from Turkey has not been described yet. On the other hand, a new form of the subgenus recently discovered in Iran (vicinities of Quazvin) possessing a karyotype quite close to that of $M$. g. strandjensis, essentially differs from the latter in morphology and shape of molars, skull and baculum (Golenishchev et al., 1999).

ACKNOWLEDGEMENTS. We are grateful to our colleagues from the Zoological Institute, Russian Academy of Sciences, Dr. Marina N. Meyer and Mr. Vladimir G. Malikov, for their valuable advises and help in the obtaining material from Turkmenistan, to Mrs. Svetlana A. Sablina for her selfsacrificing efforts to keep the collection of alive voles, studied in this research, in a good condition. Our work was financially supported by the Russian Fund of Basic Research (RFBR) grants 94-04-12382, 94-04-12383, 95-04-12546, 96-1597738, and 01-04-49657 and The State Scientific-Technical Program "Biodiversity" (project 2.1138BR).

\section{References}

Aksenova T.G. 1983. [Comparative morphological analysis of the baculum structure of the voles from tribe Microtini (Rodentia, Cricetidae). Communication 2. Genus Microtus (subgenera Pitymys, Neodon, Sumeriomys, Blanfordimys, Stenocranius)] // Trudy Zoologicheskogo Instituta RAN. Vol.119. P.48-67 [in Russian, with English summary].

Akhverdyan M.R. 1989. [Cytogenetics and systematics of the close species and twin-species of voles from the Transcaucasian fauna]. Avtoreferat Kandidatskoi Dissertatsii. Moskva. 22 p. [in Russian].

Akhverdyan M.R., Vorontsov N.N. \& Lyapunova E.A. 1991a. [On the species independence of the plateau Schidlovski' vole - Microtus schidlovskii Argyropulo, 1933 (Rodentia, Cricetidae) from the Western Armenia] // Biologicheskii Zhurnal Armenii. Vol.44. No.4. P.260-265 [in Russian].

Akhverdyan M.R., Vorontsov N.N. \& Lyapunova E.A. 1991 b. [The plateau Schidlovski' vole Microtus schidlovskii (Rodentia, Cricetidae) is an independent species from the fauna of Armenia] // Biologicheskii Zhurnal Armenii. Vol.44. No.4. P.266-271 [in Russian].

Argyropulo A.I. 1933. Über zwei neue paläarktische Wuhlmause // Zeitschrift Saugetierkunde. Bd.8. Hf.3. S.180-183.

Ashley T., Jaarola M. \& Fredga K. 1989. Absence of synapsis during pachinema of the normal sized sex chromosomes of Microtus arvalis // Hereditas. Vol.111. No.3. P.295304. 
Belcheva R.G., Peshev T.H. \& Peshev D.T. 1980. Chromosome C- and G-banding patterns in a Bulgarian population of Microtus guentheri Danford et Alston (Microtinae, Rodentia) // Genetica. No.52/53. P.45-48.

Borodin P.M. 1991. Synaptonemal complex of the common shrew Sorex araneus L. in spermatocyte spreads // Cytogenetics and Cell Genetics. Vol.56. No.1. P.61-62.

Borodin P.M., Gorlov I.P., Agulnik A.I., Agulnic S.I. \& Ruvinsky A.O. 1991. Chromosome paring and chiasme distribution in mice heterozygous for translocation in chromosomes 16 and $17 / /$ Chromosoma. Vol.101. No.2. P.262-268.

Borodin P.M., Sablina O.V., Zakiyan S.M., Nesterova T.N. \& Meyer M.N. 1991. [Morphology and behavior of the sex chromosomes in the meiosis in four species of the voles of the genus Microtus] // Genetika. Vol.27. No.6. P.10591065 [in Russian].

Chandley A. 1990. [Analysis of the meiosis in the sexual cells in the men and mouse] // Mank M. (ed.). Biology of Development of Mammals [Russian edition]. Moskva: Mir. P.99-124 [in Russian].

Corbet G.B. \& Hill J.E. 1980. A World List of Mammalian Species. London: British Museum (Natural History). 226 p.

Didier R. 1954. Etude systematique de l'os penien des Mammiferes // Mammalia. T.18. No.3. P.237-256.

Ellerman J.R. 1941. The Families and Genera of Living Rodents. London: British Museum (Natural History). Vol.2. 690 p.

Ellerman J.R. \& Morrison-Scott T.S. 1951. Checklist of Palaearctic and Indian Mammals, 1758 to 1946. London: British Museum (Natural History). 810 p.

Ford C.E. \& Hamerton J.L. 1980. A colchicine hypotonic citrate squash sequence for mammalian chromosomes // Stain Technology. No.31. P.247-251.

Golenishchev F.N. 1999. [Bacula in the subgenus Sumeriomys] // Orlov V.N. (ed.). [The VI Congress of the Russian Theriological Society. Abstracts]. Moskva: Theriologicheskoe Obshchestvo. P.58 [in Russian].

Golenishchev F.N., Malikov V.G., Arbobi M., Bulatova N.Sh., Sablina O.V. \& Polyakov A.V. 1999. Some new data on taxonomy of the genus Microtus (Rodentia, Arvicolinae) from Iran // Proceedings of the Zoological Institute RAS. Vol.281. P.15-20.

Gromov I.M. \& Polyakov I.Ya. 1977. [Voles (Microtinae). Fauna of the USSR. Mammals]. Vol.3. Vyp.8. Leningrad: Nauka. 504 p. [in Russian].

Gromov I.M. \& Erbaeva M.A. 1995. [Mammals of the Fauna of Russia and Adjacent Territories. Lagomorphs and
Rodents]. Sankt-Peterburg: Zoologicheskii Institut RAS. 522 p. [in Russian].

Harrison D.L. \& Bates P.J.J. 1991. The mammals of Arabia ( $2 \mathrm{~d}$ edition). Sevenoaks (England): Harrison Zoological Museum. 354 p.

Howell W.M. \& Black D.A. 1980. Controlled silver staining of nucleolus organizer-regions with protective colloidal developer: a one-step method // Experientia. Vol.36. No.10. P.1014-1015.

Matthey R. 1953. Les chromosomes des Muridae: revision critique et materiaux nouveaux pour servir á l'histoire de 1 evolution chromosomique chez les rongeurs // Revue suisse de Zoologie. T.60. Fasc.2. P.225-283.

Musser G.G. \& Carleton M.D. 1993. Family Muridae // Wilson D.E. \& Reeder D.M. (eds.). Mammal Species of the World. A Taxonomic and Geographic Reference. 2d edition. Washington: Smithsonian Institution Press. P.501-756.

Ogneff S.I. \& Heptner W.G. 1928. Einige Mitteilung über die Saugettiere des mittleren Kopet-Dag und der anliegend // Zoologischer Anzeiger. Bd.75. Hf.11/12. S.258-266.

Ognev S.I. 1950. [Mammals of the USSR and Adjacent Countries]. Vol.7. Moskva-Leningrad: Izdatel'stvo AN SSSR. 706 p. [in Russian].

Pavlinov I.Ya., Yakhontov E.L. \& Agadjanan A.K. 1995. [Mammals of Eurasia. I. Rodentia: Systematic and Geographic Reference Book]. Moskva: Izdatel'stvo MGU. 204 p. [in Russian].

Samner A.T. 1972. A simple technique for demonstration centromeric heterochromatin // Experimental Cell Research. Vol.75. No.2. P.304-306.

Seabright M. 1971. A rapid banding technique for human chromosomes // Lancet. Vol.11. No.7731. P.971-972.

Wang F.-g. \& Ma Y. 1982. A new subspecies of social vole from Xinjiang - Microtus socialis bogdoensis (Rodentia: Cricetidae) // Acta zootaxonomica Sinica. Vol.7. No.1. P.112-113.

Williams D., Hagen A., Runayan J. \& Lafferty D. 1971. A method for the differentiation of male meiotic chromosome stages // Journal of Heredity. Vol.62. No.1. P.17-22.

Zorenko T.A., Golenishchev F.N. \& Skinderskaya I.A. 1997. [Peculiarities of the behavior of the social voles of the subgenus Sumeriomys (Rodentia, Arvicolinae) in hybridization] // Baltic Journal of Laboratory Animals Science. No.7. P.77-102 [in Russian].

Zykov A.E. \& Zagorodnyuk I.V. 1988. [On the systematic position of the social voles (Mammalia, Rodentia) from Kopetdagh] // Vestnik zoologii. No.5. P.46-52 [in Russian]. 